\title{
Optimized Structures and Proton Affinities of Fluorinated Dimethyl Ethers: An Ab Initio Study
}

Victoria B. Orgel and David W. Ball

Cleveland State University

Cleveland, Ohio

Michael J. Zehe

Lewis Research Center

Cleveland, Ohio

September 1996

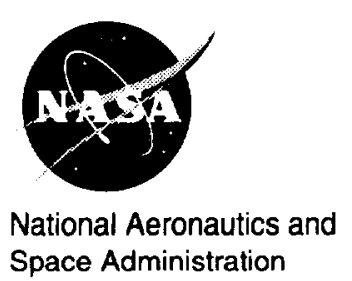




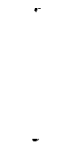




\title{
OPTIMIZED STRUCTURES AND PROTON AFFINITIES OF FLUORINATED DIMETHYL ETHERS: AN AB INITIO STUDY
}

\author{
Victoria B. Orgel and David W. Ball* \\ Department of Chemistry \\ Cleveland State University \\ Cleveland, $\mathrm{OH} 44115$ \\ Michael J. Zehe* \\ National Aeronautics and Space Administration \\ Lewis Research Center \\ Cleveland, $\mathrm{OH} 44135$
}

\begin{abstract}
$\mathrm{Ab}$ initio methods have been used to investigate the proton affinity and the geometry changes upon protonation for the molecules $\left(\mathrm{CH}_{3}\right)_{2} \mathrm{O},\left(\mathrm{CH}_{2} \mathrm{~F}\right)_{2} \mathrm{O},\left(\mathrm{CHF}_{2}\right)_{2} \mathrm{O}$, and $\left(\mathrm{CF}_{3}\right)_{2} \mathrm{O}$. Geometry optimizations were performed at the MP2/3-21G level, and the resulting geometries were used for single-point energy MP2/6-31G** calculations. The proton affinity calculated for $\left(\mathrm{CH}_{3}\right)_{2} \mathrm{O}$ was $7 \mathrm{Kjoule} / \mathrm{mole}$ from the experimental value, within the desired variance of $+1-8 \mathrm{Kjoule} /$ mole for $\mathrm{G} 2$ theory, suggesting that the methodology used in this study is adequate for energy difference considerations. For $\left(\mathrm{CF}_{3}\right)_{2} \mathrm{O}$, the calculated proton affinity of $602 \mathrm{Kjoule/mole} \mathrm{suggests} \mathrm{that} \mathrm{perfluorinated} \mathrm{ether} \mathrm{molecules} \mathrm{do} \mathrm{not} \mathrm{act} \mathrm{as} \mathrm{Lewis} \mathrm{bases} \mathrm{under}$ normal circumstances; e.g. degradation of commercial lubricants in tribological applications.
\end{abstract}

\section{INTRODUCTION}

Perfluoroalkyl ethers exhibit high physical and chemical stability and have low vapor pressure. These qualities make them an excellent choice for lubricants in computer disk drive platters and satellite bearings. They are being intensively studied in order to develop a better understanding of the mechanisms of their catalytic decomposition on metal and metal oxide surfaces [1-6]. One predominant theory suggests that the reaction is initiated by weak Lewis acid-base interactions at the metal-ether interface [7]. Atoms on the metal surface act as Lewis acid sites which interact with basic oxygen sites on the ethers. Kasai et al. studied the breakdown of a series of commercial perfluoroalkyl ethers on $\mathrm{Al}_{2} \mathrm{O}_{3}$ [8] and $\mathrm{AlCl}_{3}[9]$ at elevated temperatures. Based on the reactants, the identity and distribution of products, and the relative reactivities of the lubricants, the authors proposed a credible mechanism: two adjacent oxygen atoms adsorb simultancously onto a metal acid site, inducing a charge on the attached carbon atoms which, in turn, causes a fluorine atom to migrate and a bond to cleave. The cleaved molecule then continues to fragment.

Other mechanisms for the catalytic breakdown have been suggested [10]. While the reactivity of non-fluorinated ethers is governed by their acid-base chemistry, the substitution of one or more of the ether hydrogens by fluorine is expected to decrease the basicity of the oxygen atom. Also, the reaction of one oxygen in a polyether is expected to reduce the basicity of the other oxygen(s). Other basic sites on the fluoroether chain, e.g. the fluorine atoms, may participate in a reaction with surface acid sites, and the reaction could be dissociative. For these reasons, it is of interest to study the basicities of polyalkyl ethers with varying levels of fluorine substitution.

A convenient indicator of basicity is the proton affinity [11], which is defined as the negative enthalpy of gas-phase protonation; for example:

$$
\left(\mathrm{CH}_{3}\right)_{2} \mathrm{O}+\mathrm{H}^{+} \rightarrow\left(\mathrm{CH}_{3}\right)_{2} \mathrm{OH}^{+} \quad \mathrm{PA}\left[\left(\mathrm{CH}_{3}\right)_{2} \mathrm{O}\right] \equiv-\Delta \mathrm{H}_{\mathrm{rxnn}}
$$


While proton affinity (PA) is a measure of the ether reactivity to a single proton only, the values show correlation to other scales of basicity such as ionization energies. Gaseous basicities (which are indicative of the $\Delta \mathrm{G}$ of protonation) and proton affinities (indicative of the $\Delta H$ of protonation) differ because of the entropy contribution, but their relative values are similar for a series of molecules. Proton affinities can be measured experimentally using high pressure mass spectrometry or ion-cyclotron resonance spectrometry. Although the results from these methods are well accepted, the site of protonation can be unclear in complicated molecules, and the existence of decomposition pathways can interfere with the results. These problems are especially serious with experimental study of fluoroether protonation, because of their tendency to split off hydrogen fluoride. Little experimental work has been conducted on the measurement of the basicities or proton affinities of partially-or fully-fluorinated ethers.

Proton affinity values can be calculated using a variety of theoretical molecular orbital techniques. $\mathrm{Ab}$-initio methods yield very accurate results for molecules composed of first-row elements [12], and an extensive literature exists covering proton affinity determination using these methods. This work deals with the determination of proton affinities of $\left(\mathrm{CF}_{3}\right)_{2} \mathrm{O},\left(\mathrm{CH}_{2} \mathrm{~F}\right)_{2} \mathrm{O},\left(\mathrm{CHF}_{2}\right)_{2} \mathrm{O}$, and $\left(\mathrm{CH}_{3}\right)_{2} \mathrm{O}$ by ab-initio methods including electron correlation using Moeller-Plesset perturbation theory. The purpose is to obtain accurate proton affinities for these difficult-to-measure molecules, and to illuminate the discussion regarding breakdown mechanisms for polyperfluoroalkylether lubricants.

Previous ab-initio calculations of proton affinities for fluoroethers have been performed by DelHalle et al. [13,14], who published Hartree-Fock (SCF) results for a series of unprotonated and protonated ethers and their perfluorinated analogues, using the 3-21G and 6-31G* basis sets. The authors found that perfluorination of hydrocarbon ethers resulted in a proton affinity decrease of over $300 \mathrm{~kJ} / \mathrm{mole}$. These calculations were performed, however, without considering electron correlation. Earlier, Pacansky et al. [15] studied the structures and vibrational spectra for a series of perfluoroethers with Hartree-Fock calculations using a 3-21G basis set. These authors found accurate results for geometries and excellent agreement with measured vibrational frequencies "even at the 3-21G level" [15]. This work did not consider electron correlation effects. More recently, Schwartz et al. [16,17] and Smith, Jaffe, and Yoon [18] used ab-initio methods to study the conformational characteristics of simple fluoroethers, and related their results to the structural characteristics of polymeric perfluoroethers.

In an attempt to delineate the effect of stepwise fluorine substitution at the ether, we herein present a survey of calculated proton affinities of four symmetrically substituted dimethyl ethers containing varying amounts of fluorine, using second-order Moeller-Plesset (MP2) perturbation theory and a 6-31G** basis set, applied to geometries determined with a 3-21G basis set (MP2/6-31G**//MP2/3-21G). This paper expands on earlier work by using bigger basis sets and including the effects of electron correlation.

\section{COMPUTATIONAL DETAILS}

Structural parameters and single-point energy values were determined with the use of the Gaussian 92 computer package [19]. The calculations were performed on a Cray C-90 or a Cray Y-MP8 supercomputer. The geometry optimizations were carried out using a 3-21G basis set at the MP2 level of theory. The resulting optimized structures were then used to determine MP2 single-point energies with a 6-31G** basis set [20]. A staggered $C_{2}$ symmetry was chosen as the initial geometry; a rotational potential energy surface to scan for metastable geometries was not performed in this study, but will be reported later [21]. The $C_{2}$ symmetry implies that, for the partially-fluorinated ethers, the unique atoms in each methyl group were initially placed on opposite sides of the $\mathrm{C}-\mathrm{O}-\mathrm{C}$ plane. This was assumed to be the lowest-energy conformation. (More recent results confirm that these are the lowest-energy conformations for both ethers [21].) Frequency calculations were performed on the optimized structures, and the absence of any imaginary values confirmed that the optimized structures were true energy minima. These computations also yielded thermal energy values. Protonation was assumed to occur at the oxygen atom in all cases [22]. Proton affinities were then calculated as follows:

$$
\mathrm{PA}=-\Delta \mathrm{H}_{298}=-\left(\Delta \mathrm{E}_{0}+\Delta \mathrm{E}_{\text {therm }}+\Delta(\mathrm{PV})\right)
$$


where $\Delta \mathrm{E}_{0}$ is the difference in the total electronic energies at $0 \mathrm{~K}$, and $\Delta \mathrm{E}_{\text {therm }}$ includes contributions from the zero-point and thermal vibrational energy (scaled by a factor of 0.95 ), rotational energy, and thermal translational energy differences. $\Delta(\mathrm{PV})$ is the standard conversion from internal energy to enthalpy and in this case equals $-\mathrm{RT}(=-2.47 \mathrm{~kJ} / \mathrm{mole})$. Higher level corrections were ignored, as they were predicted to be of negligible value and expected to mostly cancel in difference calculations.

\section{RESULTS AND DISCUSSION}

Structures The structural parameters for optimized $\left(\mathrm{CH}_{3}\right)_{2} \mathrm{O},\left(\mathrm{CFH}_{2}\right)_{2} \mathrm{O},\left(\mathrm{CF}_{2} \mathrm{H}\right)_{2} \mathrm{O}$, and $\left(\mathrm{CF}_{3}\right)_{2} \mathrm{O}$ along with their protonated counterparts are listed in Tables 1 to 4, respectively. Diagrams illustrating the optimized geometries are shown in Figs. 1-8. For this study, unprotonated ether starting geometries were assumed to contain conformationally equivalent methyl groups, which imposed a $C_{2}$ symmetry on the molecular geometry. The initial geometries of the protonated ethers had $C_{1}$ geometries and no structural parameters were constrained. It was felt that the rotational conformational isomerism of the methyl groups would have negligible effect on the proton affinity. Determination of the potential energy surface with respect to methyl rotations in both the unprotonated and protonated ethers is currently underway [21].

The initial optimization of $\left(\mathrm{CH}_{3}\right)_{2} \mathrm{O}$ yielded a structure in which the methyl groups were slightly rotated $\left(<5^{\circ}\right)$ out of the $\mathrm{C}-\mathrm{O}-\mathrm{C}$ plane. This was unexpected, since it was thought that a $C_{2 v}$ symmetry would have the lowest energy. Upon constraining the molecule to a $C_{2 v}$ symmetry and re-optimizing the other structural parameters, an electronic energy minimum was calculated that was indeed slightly lower $(\sim 8 \mathrm{Kj}$ mole $^{-1}$ ) than the initial optimized structure. We therefore use this constrained geometry as our reported result, and conclude that dimethyl ether has a relatively flat potential energy surface near its minimum-energy geometry.

For $\left(\mathrm{CH}_{3}\right)_{2} \mathrm{O}, \mathrm{H} 1$ and $\mathrm{H} 4$ (see Fig. 1 for labeling) are in the $\mathrm{C}-\mathrm{O}-\mathrm{C}$ plane, and the molecule exhibits a $C_{2 v}$ symmetry. This is similar to the optimized structure of diethyl ether, $\left(\mathrm{C}_{2} \mathrm{H}_{5}\right)_{2} \mathrm{O}$, which also optimized to $C_{2 v}$ symmetry under similar optimization conditions [ 23]. Upon substitution of $\mathrm{F}$ for all hydrogens, the departure from $C_{2 v}$ symmetry is pronounced, due to the larger van der Waals radius of the fluorine atom. Table 4 shows that F1 and F4 (see Fig. 7) are $36.4^{\circ}$ out of the C-O-C molecular plane. Curiously, the substitution of only one or two of the hydrogen atoms with fluorine on both methyl groups did little to change the rotation of the methyl groups out of the $\mathrm{C}-\mathrm{O}-\mathrm{C}$ plane.

Increasing the fluorine content of the ether methyl groups had little effect on the length of the methyl C-H bonds; a slight decrease was observed (on the order of $0.02 \AA$ ). The C-O-C bond angle increased slightly and then dramatically upon increased fluorination; this is doubtless due to van der Waals repulsion between the fluorine atoms on either side of the oxygen atom. The $\mathrm{C}-\mathrm{O}$ bond lengths also exhibited a monotonic drop of about $0.02 \AA$ per fluorination step. Otherwise, bond distances and bond angles were standard for fluoro- or hydrocarbon compounds.

The protonated ethers optimized with no symmetry elements (except $E$ ) and, in several cases, differently-reoriented methyl groups (see Figs.). There was an obvious fluorine effect on the length of the $\mathrm{O}-\mathrm{H}$ bond. The effect is small (the net change is $0.01 \AA$ ), but it monotonically increases with increased fluorine substitution. This should correlate well with proton affinity trends. More obviously, the angle that the added proton makes with the $\mathrm{C}-\mathrm{O}-\mathrm{C}$ plane also changes with fluorine content. For $\left(\mathrm{CH}_{3}\right)_{2} \mathrm{OH}^{+}$, the proton is $40^{\circ}$ out of the $\mathrm{C}-\mathrm{O}-\mathrm{C}$ plane. However, for $\left(\mathrm{CF}_{3}\right)_{2} \mathrm{OH}^{+}$, it is almost exactly in the plane. There is no trend in the $\mathrm{C}-\mathrm{O}-\mathrm{C}$ bond angles versus fluorination in the protonated ethers, since the effect of the added proton probably overwhelms any other trend. Protonation of $\left(\mathrm{CH}_{3}\right)_{2} \mathrm{O}$ and $\left(\mathrm{CFH}_{2}\right)_{2} \mathrm{O}$ does not substantially change the relative orientations of the methyl groups. However, there is a very marked rotation of both $\mathrm{CF}_{2} \mathrm{H}$ groups upon protonation of $\left(\mathrm{CF}_{2} \mathrm{H}\right)_{2} \mathrm{O}$, with one group rotating about $30^{\circ}$ and the other about $60^{\circ}$. The $\mathrm{CF}_{2} \mathrm{H}$ group that rotates $60^{\circ}$ has one of its fluorine atoms almost in the C-O-C plane and is only $2.33 \AA$ away from the added proton. It seems fair to conclude that there is some intramolecular hydrogen bonding occurring to force this difluoromethyl group to rotate so much.

For $\left(\mathrm{CF}_{3}\right)_{2} \mathrm{O}$, the rotations of the methyl groups are on the order of $70^{\circ}$ from the unprotonated ether. There is a significant change in methyl group orientation upon protonation, the largest change for any of the 
ethers. However, unlike $\left(\mathrm{CF}_{2} \mathrm{H}\right)_{2} \mathrm{O}$, where only one methyl substituent rotates significantly, in perfluorodimethyl ether both methyl groups rotate upon protonation. This rotation allows one fluorine atom from each $\mathrm{CF}_{3}$ group to approach the added proton to a distance of about $2.36 \AA$; once again, this is probably close enough to assume some hydrogen-bonding type of interaction. Closer approach is probably blocked by van der Waals repulsion of the other, nearly-eclipsing fluorine pair on the underside of the $\mathrm{C}-\mathrm{O}-\mathrm{C}$ bond angle (i.e. distal to the added proton).

Proton Affinities Experimental data is available only for $\left(\mathrm{CH}_{3}\right)_{2} \mathrm{O}$, which has a PA of $804 \mathrm{~kJ} / \mathrm{mole}$ [11]. The 3-21G basis set results in a relatively poor calculated PA for this molecule. However, the MP2 single point energies using the $6-31 \mathrm{G}^{* *}$ basis set yield a proton affinity of $810.7 \mathrm{~kJ} / \mathrm{mole}$, a variance of $\sim 7 \mathrm{~kJ} /$ mole or $0.8 \%$. The absolute variance is within the desired $\pm 8 \mathrm{~kJ} /$ mole variance for $\mathrm{G} 2$ theory, [24] suggesting that the methodology used in this study is adequate for energy difference considerations.

Additional polarization and diffuse functions were added to the proton for the optimizations of the protonated ethers with the thought that such an augmentation would allow for a better description of the interactions of the proton with the ether. After optimization, however, all frequency calculations yielded at least one negative vibration. We therefore abandoned this course of investigation and, cognizant of the potential impact on our results, determined the proton affinities in the absence of the hydrogen basis set augmentation. To illustrate the importance of electron correlation, $\mathrm{HF} / 6-31 \mathrm{G}^{* *}$ and $\mathrm{MP} 2 / 6-31 \mathrm{G}^{* *}$ singlepoint-energy-derived PAs were calculated. Table 5 shows the calculated proton affinities for the four ethers studied here. In only one case, $\left(\mathrm{CFH}_{2}\right)_{2} \mathrm{O}$, are the $\mathrm{HF}$ and $\mathrm{MP2}$ values for the proton affinity similar. In the other three cases, differences of 6-23 kJ/mole are found.

On the presumption that a similar error exists for the other ethers where no experimental data exist, the calculated PA's in Table 5 show the expected trend: a decrease upon increased fluorination. Although both columns of PA's show the same relative change, the 6-31G** calculations are expected to provide values closer to experimental data, should they ever be determined. For the fully-fluorinated ether, the (MP2) calculated proton affinity of $602.0 \mathrm{~kJ} /$ mole is comparable to the experimental PAs of the molecules COS, $\mathrm{HI}$ or $\mathrm{C}_{3} \mathrm{H}_{8}$ [Lias et al., 11]. These last three compounds do not act as Lewis bases under usual circumstances, so it is expected that the fully fluorinated dimethyl ether would not either.

The geometry for $\left(\mathrm{CF}_{3}\right)_{2} \mathrm{O}$ compares well with results of the two studies by Delhalle et al. [13,14]. They determined a ZPVE-corrected proton affinity of 556.5 and $560.7 \mathrm{~kJ} /$ mole for perfluorodimethyl ether using the 3-21G and the 6-31G* basis sets, respectively. Our MP2 results include some level of electron correlation, which accounts for part of a difference of $+40 \mathrm{~kJ} / \mathrm{mole}$ in the calculated proton affinity. In addition, comparison of our MP2/6-31G**//MP2/3-21G proton affinity results with experimental data for dimethyl ether and two of the diethyl ethers [23] shows very good agreement, with an average difference of $\pm 5 \mathrm{~kJ} / \mathrm{mole}$. This suggests that the MP2/6-31G**//MP2/3-21G methodology does a more than adequate job of predicting the proton affinities of fluorinated ethers [20].

If these proton affinity predictions apply to larger fluoroether polymers, they collectively suggest a very weak base behavior at the oxygen atoms. While this does not disprove the hypothesis that Lewis acidbase mechanisms are the first step in polyperfluoroether lubricants, it suggests that such interactions may not be energetically favorable. We are continuing to investigate the properties of these compounds to better understand how fluoroethers interact with protons, metal ions, and metal oxide surfaces.

\section{ACKNOWLEDGMENTS}

DWB and VBO would like to thank the Ohio Supercomputing Center, Columbus, $\mathrm{OH}$, where some of this work was performed, for Grant \#PFS183-3. MJZ acknowledges a grant of computer time from NASA Ames Research Center. We would also like to thank Dr. Richard Jaffe of NASA Ames Research Center for helpful suggestions. 


\section{REFERENCES}

1. W.R. Jones, K.J.L. Paciorek, T.I. Ito, R.H. Kratzer. Ind. Eng. Chem. Prod. Res. Dev. 1983, $22,166$.

2. S. Mori, W. Morales. J. Vac. Sci. Technol. A 1990, 8, 3354.

3. M.E. Napier, P.C. Stair. J. Vac. Sci. Technol. A 1992, 10, 2704.

4. W. Morales. NASA Tech. Paper 2774, November 1987.

5. L.S. Helmick, W.R. Jones. NASA Tech. Memo. 102493. February 1990.

6. J. Pacansky, R.J. Waltman. J. Phys. Chem. 1991, 95, 1512.

7. P. Kasai. Macromolecules 1992, 25, 6791.

8. P. Kasai, W.T. Tang, P. Wheeler. Appl. Surf. Sci. 1991, 51, 201.

9. P. Kasai, P. Wheeler. Appl. Surf. Sci. 1991, 52, 91.

10. M.J. Zehe, O. Faut. NASA Tech. Memo. 101962. October 1989.

11. S.G. Lias, J.G. Leibman, R.D. Levin. J. Phys. Chem. Ref. Data 1984, 13, 695.

12. B.J. Smith, L. Radom. J. Am. Chem. Soc. 1993, 115, 4885.

13. M. Fontaine, J. Delhalle, M. Defranceschi, G. Lecayon. Int. J. Quant. Chem. 1993, 46, 171.

14. M. Fontaine, J. Delhalle, M. Defranceschi, J.M.M. Bourin. J. Mol. Struct. 1993, 300, 607

15. J. Pacansky, M. Miller, W. Hutton, V. Liu, A. Scheiner. J. Am. Chem. Soc. 1991, 113, 329.

16. C.L. Stanton, H.L. Paige, and M. Schwartz. J. Phys. Chem. 97, 5901 (1993)

17. C.L. Stanton and M. Schwartz. J. Phys. Chem. 97, 11221 (1993)

18. G.D. Smith, R.L. Jaffe, D.Y. Yoon Macromolecules 1995, 28(17), 5804

19. GAUSSIAN 92. Revisions B and D.2. M.J. Frisch, G.W. Trucks, M. Head-Gordon, P.M.W. Gill, M.W. Wong, J.B. Foresman, B.G. Johnson, H.B. Schlegel, M.A. Robb, E.S. Replogle, R. Gomperts, J.L. Andres, K. Raghavachari, J.S. Binkley, C. Gonzales, R.L. Martin, D.J. Fox, D.J. Defrees, J. Baker, J.J.P. Stewart, and J.A. Pople; Gaussian, Inc., Pittsburgh, PA, 1992.

20. W.J. Hehre, L. Radom, P.v.R. Schleyer, J.A. Pople. "Ab Initio Molecular Orbital Theory" J. Wiley and Sons: New York, 1986. A discussion of the basis set dependence on the calculated absolute basicity can be found on pages $310-321$.

21. V.B. Orgel, D.W. Ball. Work in progress.

22. See, however, D.W. Ball. High Temp. Matl. Sci. 1995, 33, 171.

23. M.J. Zehe, D.W. Ball. Manuscript in preparation.

24. L.A. Curtiss, K. Raghavachari, G.W. Trucks, J.A. Pople. J. Chem. Phys. 1991, 94, 7221. 
Table 1

Optimized Structural Parameters for $\left(\mathrm{CH}_{3}\right)_{2} \mathrm{O}$ and $\left(\mathrm{CH}_{3}\right)_{2} \mathrm{OH}^{+}$

Based on MP2/3-21G Optimization

Bond Length, $\AA$

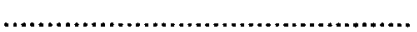

$\begin{array}{lcc}\text { Bond } & \left(\mathrm{CH}_{3}\right)_{2} \mathrm{O} & \left(\mathrm{CH}_{3}\right)_{2} \mathrm{OH}^{+} \\ & & \\ \mathrm{C} 1-\mathrm{O} & 1.467 & 1.532 \\ \mathrm{C} 2-\mathrm{O} & 1.467 & 1.532 \\ \mathrm{C} 1-\mathrm{H} 1 & 1.100 & 1.087 \\ \mathrm{C} 1-\mathrm{H} 2 & 1.100 & 1.088 \\ \mathrm{C} 1-\mathrm{H} 3 & 1.091 & 1.090 \\ \mathrm{C} 2-\mathrm{H} 4 & 1.100 & 1.087 \\ \mathrm{C} 2-\mathrm{H} 5 & 1.091 & 1.090 \\ \mathrm{C} 2-\mathrm{H} 6 & 1.100 & 1.088 \\ \mathrm{O}-\mathrm{H}^{+} & & 0.995\end{array}$

Angular Values, Degrees

$\begin{array}{cc}\left(\mathrm{CH}_{3}\right)_{2} \mathrm{O} & \left(\mathrm{CH}_{3}\right)_{2} \mathrm{OH} \\ & \\ 110.4 & 118.2 \\ 108.3 & 111.7 \\ 109.4 & 113.0 \\ 109.5 & 112.7 \\ 109.5 & 113.0 \\ 111.8 & 104.7 \\ 111.8 & 105.4 \\ 106.0 & 108.6 \\ 111.8 & 108.6 \\ 106.0 & 105.4 \\ 111.8 & 104.7 \\ -60.8 & -179.9 \\ -60.8 & -179.9 \\ & 44.99 \\ & -45.00\end{array}$


Table 2

Optimized Structural Parameters for $\left(\mathrm{CFH}_{2}\right)_{2} \mathrm{O}$ and $\left(\mathrm{CFH}_{2}\right)_{2} \mathrm{OH}^{+}$

Based on MP2/3-21G Optimization

Bond Length, $\AA$

$\begin{array}{lcc} & & \\ \text { Bond } & \left(\mathrm{CFH}_{2}\right)_{2} \mathrm{O} & \left(\mathrm{CFH}_{2}\right)_{2} \mathrm{OH}^{+} \\ \mathrm{C} 1-\mathrm{O} & 1.441 & 1.544 \\ \mathrm{C} 2-\mathrm{O} & 1.441 & 1.563 \\ \mathrm{C} 1-\mathrm{F} 1 & 1.419 & 1.376 \\ \mathrm{C} 1-\mathrm{H} 1 & 1.090 & 1.081 \\ \mathrm{C} 1-\mathrm{H} 2 & 1.087 & 1.086 \\ \mathrm{C} 2-\mathrm{F} 2 & 1.419 & 1.371 \\ \mathrm{C} 2-\mathrm{H} 3 & 1.090 & 1.086 \\ \mathrm{C} 2-\mathrm{H} 4 & 1.087 & 1.085 \\ \text { O-H } & & 1.000\end{array}$

Angular Values, Degrees

\begin{tabular}{lcc}
\multicolumn{1}{c}{ Angle } & $\left(\mathrm{CFH}_{2}\right)_{2} \mathrm{O}$ & $\left(\mathrm{CFH}_{2}\right)_{2} \mathrm{OH}^{+}$ \\
$\mathrm{C} 1-\mathrm{O}-\mathrm{C} 2$ & 112.0 & 114.9 \\
$\mathrm{~F} 1-\mathrm{C} 1-\mathrm{H} 1$ & 107.9 & 112.7 \\
$\mathrm{H} 1-\mathrm{C} 1-\mathrm{H} 2$ & 112.6 & 115.7 \\
$\mathrm{~F} 2-\mathrm{C} 2-\mathrm{H} 3$ & 107.9 & 112.2 \\
$\mathrm{H} 3-\mathrm{C} 2-\mathrm{H} 4$ & 112.6 & 116.2 \\
$\mathrm{O}-\mathrm{C} 1-\mathrm{F} 1$ & 110.5 & 106.3 \\
$\mathrm{O}-\mathrm{C} 1-\mathrm{H} 1$ & 110.4 & 103.1 \\
$\mathrm{O}-\mathrm{C} 1-\mathrm{H} 2$ & 105.6 & 104.3 \\
$\mathrm{O}-\mathrm{C} 2-\mathrm{F} 2$ & 110.5 & 103.0 \\
$\mathrm{O}-\mathrm{C} 2-\mathrm{H} 3$ & 110.3 & 106.5 \\
$\mathrm{O}-\mathrm{C} 2-\mathrm{H} 4$ & 105.5 & 103.9 \\
$\mathrm{~F} 1-\mathrm{C} 1-\mathrm{O}-\mathrm{C} 2$ & -176.6 & 179.5 \\
$\mathrm{~F} 2-\mathrm{C} 2-\mathrm{O}-\mathrm{C} 1$ & -177.4 & 164.9 \\
$\mathrm{H}^{+}-\mathrm{O}-\mathrm{C} 1-\mathrm{F} 3$ & & 40.38 \\
$\mathrm{H}^{+}-\mathrm{O}-\mathrm{C} 2-\mathrm{F} 5$ & & -55.77
\end{tabular}


Table 3

Optimized Structural Parameters for $\left(\mathrm{CF}_{2} \mathrm{H}\right)_{2} \mathrm{O}$ and $\left(\mathrm{CF}_{2} \mathrm{H}\right)_{2} \mathrm{OH}^{+}$

Based on MP2/3-21G Optimization

Bond Length, ^̊

$\begin{array}{lcc}\text { Bond } & \left(\mathrm{CF}_{2} \mathrm{H}\right)_{2} \mathrm{O} & \left(\mathrm{CF}_{2} \mathrm{H}\right)_{2} \mathrm{OH}^{+} \\ \mathrm{C} 1-\mathrm{O} & 1.422 & 1.571 \\ \mathrm{C} 2-\mathrm{O} & 1.422 & 1.544 \\ \mathrm{C} 1-\mathrm{F} 1 & 1.395 & 1.339 \\ \mathrm{C} 1-\mathrm{F} 2 & 1.367 & 1.348 \\ \mathrm{C} 1-\mathrm{H} 1 & 1.084 & 1.078 \\ \mathrm{C} 2-\mathrm{F} 3 & 1.395 & 1.355 \\ \mathrm{C} 2-\mathrm{F} 4 & 1.367 & 1.344 \\ \mathrm{C} 2-\mathrm{H} 2 & 1.084 & 1.081 \\ \mathrm{O}-\mathrm{H}^{+} & & 1.001\end{array}$

Angular Values, Degrees

\begin{tabular}{lcc}
\multicolumn{1}{c}{ Angle } & $\left(\mathrm{CF}_{2} \mathrm{H}_{2} \mathrm{O}\right.$ & $\left(\mathrm{CF}_{2} \mathrm{H}_{2} \mathrm{OH}^{+}\right.$ \\
& 113.5 & 123.0 \\
C1-O-C2 & 113.5 & 112.7 \\
F1-C1-F2 & 109.1 & 114.5 \\
F2-C1-H1 & 111.2 & 112.6 \\
F3-C2-F4 & 109.1 & 114.2 \\
F4-C2-H2 & 111.2 & 105.5 \\
O-C1-F1 & 108.9 & 101.8 \\
O-C1-F2 & 106.7 & 105.6 \\
O-C1-H1 & 112.2 & 101.6 \\
O-C2-F3 & 108.9 & 106.0 \\
O-C2-F4 & 106.7 & 106.9 \\
O-C2-H2 & 112.2 & 37.57 \\
F2-C1-O-C2 & 68.29 & 120.9 \\
F4-C2-O-C1 & 63.38 & -121.4 \\
$\mathrm{H}^{+}-\mathrm{O}-\mathrm{C} 1-\mathrm{H} 1$ & & -70.54 \\
$\mathrm{H}^{+}-\mathrm{O}-\mathrm{C} 2-\mathrm{H} 2$ & &
\end{tabular}


Table 4

Optimized Structural Parameters for $\left(\mathrm{CF}_{3}\right)_{2} \mathrm{O}$ and $\left(\mathrm{CF}_{3}\right)_{2} \mathrm{OH}^{+}$

Based on MP2/3-21G Optimization

Bond Length, $\AA$

$\begin{array}{lcc} & \left(\mathrm{CF}_{3}\right)_{2} \mathrm{O} & \left(\mathrm{CF}_{3}\right)_{2} \mathrm{OH}^{+} \\ \mathrm{C} 1-\mathrm{O} & 1.404 & 1.551 \\ \mathrm{C} 2-\mathrm{O} & 1.404 & 1.551 \\ \mathrm{C} 1-\mathrm{F} 1 & 1.350 & 1.327 \\ \mathrm{C} 1-\mathrm{F} 2 & 1.360 & 1.331 \\ \mathrm{C} 1-\mathrm{F} 3 & 1.367 & 1.331 \\ \mathrm{C} 2-\mathrm{F} 4 & 1.351 & 1.327 \\ \mathrm{C} 2-\mathrm{F} 5 & 1.360 & 1.331 \\ \mathrm{C} 2-\mathrm{F} 6 & 1.367 & 1.331 \\ \mathrm{O}^{+} \mathrm{H}^{+} & & 1.004\end{array}$

Angular Values, Degrees

$\begin{array}{lcc}\text { Angle } & \left(\mathrm{CF}_{3}\right)_{2} \mathrm{O} & \left(\mathrm{CF}_{3}\right)_{2} \mathrm{OH}^{+} \\ \text {C1-O-C2 } & 119.2 & 122.6 \\ \text { F1-C1-F2 } & 109.3 & 113.3 \\ \text { F2-C1-F3 } & 108.5 & 114.2 \\ \text { F4-C2-F5 } & 109.3 & 113.4 \\ \text { F5-C2-F6 } & 108.5 & 114.2 \\ \text { O-C1-F1 } & 107.1 & 107.1 \\ \text { O-C1-F2 } & 111.4 & 104.0 \\ \text { O-C1-F3 } & 110.8 & 103.6 \\ \text { O-C2-F4 } & 107.1 & 107.0 \\ \text { O-C2-F5 } & 111.4 & 103.6 \\ \text { O-C2-F6 } & 110.8 & 104.0 \\ \text { F1-C1-O-C2 } & 36.7 & -156.3 \\ \text { F4-C2-O-C1 } & 36.7 & 85.5 \\ \mathrm{H}^{+}-\mathrm{O}-\mathrm{C} 1-\mathrm{F} 3 & & 25.8 \\ \mathrm{H}^{+}-\mathrm{O}-\mathrm{C} 2-\mathrm{F} 5 & & 23.3\end{array}$

Table 5

Theoretical proton affinities for various dimethyl ethers.

Proton Affinity at $298 \mathrm{~K}, \mathrm{~kJ} / \mathrm{mole}$

\begin{tabular}{|c|c|c|c|}
\hline PA Reaction & $\mathrm{MP} 2 / 3-21 \mathrm{G}$ & $\begin{array}{l}\mathrm{HF} / 6-31 \mathrm{G}^{* *} \\
/ / \mathrm{MP} 2 / 3-21 \mathrm{G}\end{array}$ & $\begin{array}{l}\mathrm{MP} 2 / 6-31 \mathrm{G}^{* *} \\
/ \mathrm{MP} 2 / 3-21 \mathrm{G}\end{array}$ \\
\hline$\left(\mathrm{CH}_{3}\right)_{2} \mathrm{O}+\mathrm{H}^{+} \longrightarrow\left(\mathrm{CH}_{3}\right)_{2} \mathrm{OH}^{+}$ & 836.1 & 831.0 & 810.7 \\
\hline$\left(\mathrm{CFH}_{2}\right)_{2} \mathrm{O}+\mathrm{H}^{+} \rightarrow\left(\mathrm{CFH}_{2}\right)_{2} \mathrm{OH}^{+}$ & 755.8 & 769.4 & 767.9 \\
\hline$(\mathrm{CF}, \mathrm{H}), \mathrm{O}+\mathrm{H}^{+} \rightarrow\left(\mathrm{CF}_{2} \mathrm{H}\right)_{2} \mathrm{OH}^{+}$ & 699.5 & 655.9 & 667.5 \\
\hline$\left(\mathrm{CF}_{3}\right)_{2} \mathrm{O}+\mathrm{H}^{+} \longrightarrow\left(\mathrm{CF}_{3}\right)_{2} \mathrm{OH}^{+}$ & 630.2 & 577.7 & 602.0 \\
\hline
\end{tabular}




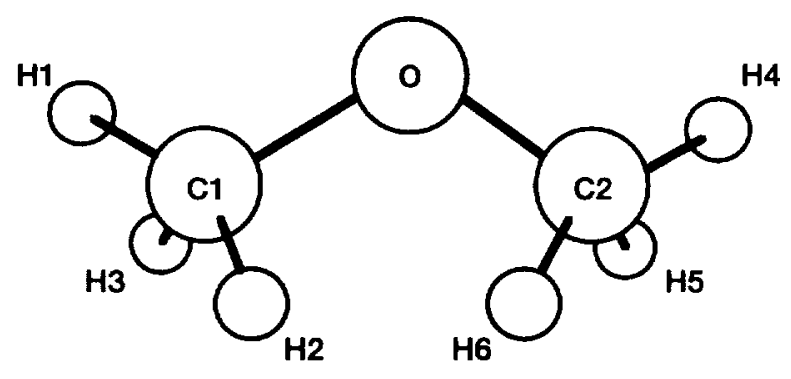

Figure 1.-Optimized structure of $\left(\mathrm{CH}_{3}\right)_{2} \mathrm{O}$. Cr. Table I.

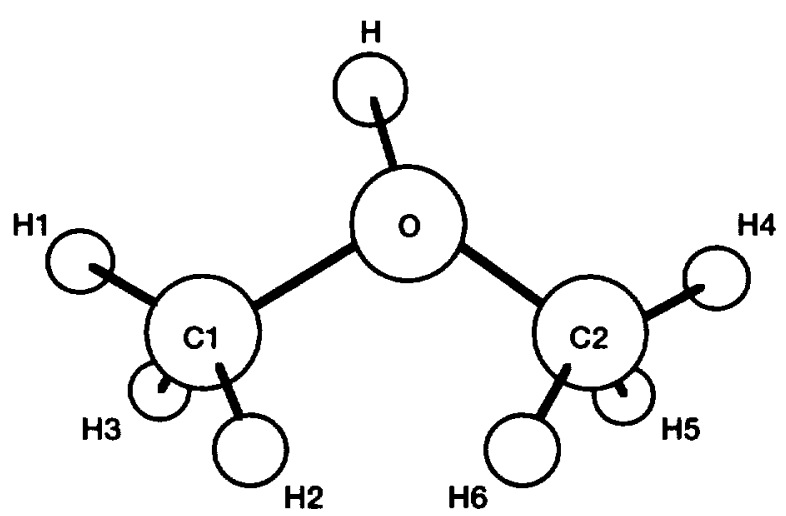

Figure 2.-Optimized structure of $\left(\mathrm{CH}_{3}\right)_{2} \mathrm{OH}^{+}$. Cf. Table I.

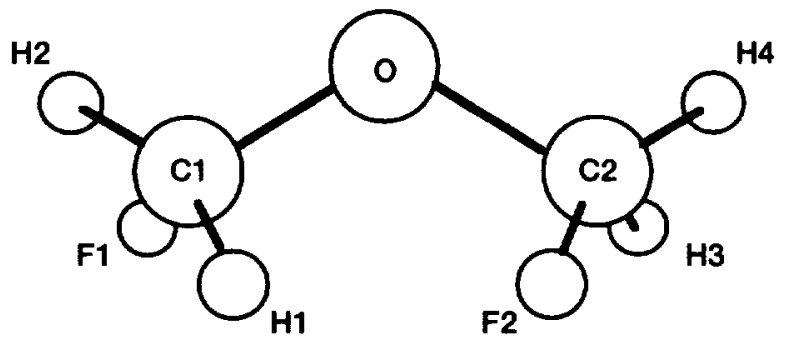

Figure 3.-Optimized structure of $\left(\mathrm{CFH}_{2}\right)_{2} \mathrm{O}$. Cf. Table II. 


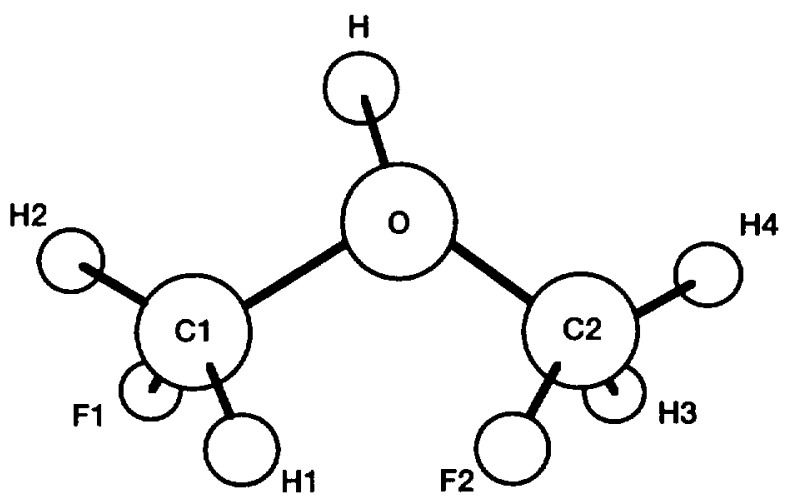

Figure 4.-Optimized structure of $\left(\mathrm{CFH}_{2}\right)_{2} \mathrm{OH}^{+}$. Cf. Table II.

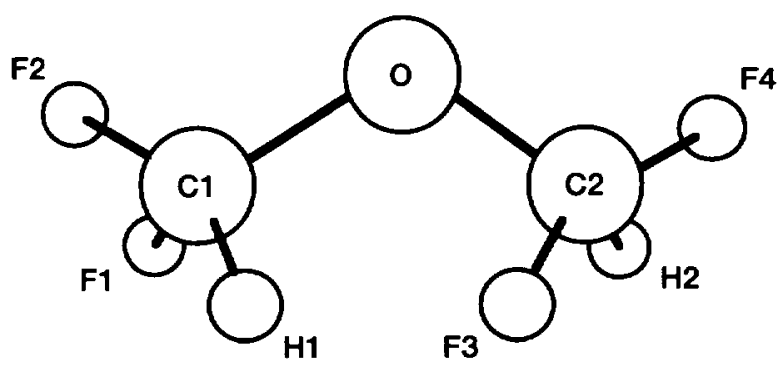

Figure 5.-Optimized structure of $\left(\mathrm{CF}_{2} \mathrm{H}\right)_{2} \mathrm{O}$. Cf. Table III.

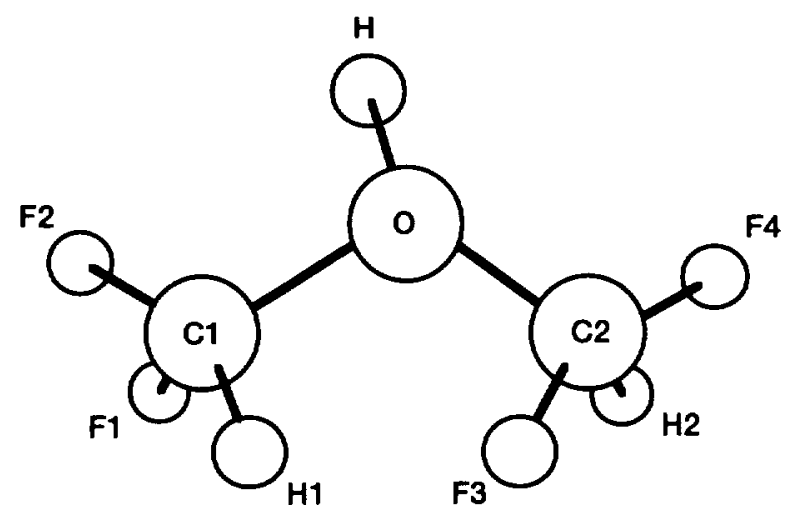

Figure 6.-Optimized structure of $\left(\mathrm{CF}_{2} \mathrm{H}\right)_{2} \mathrm{OH}^{+}$.

Cf. Table III. 


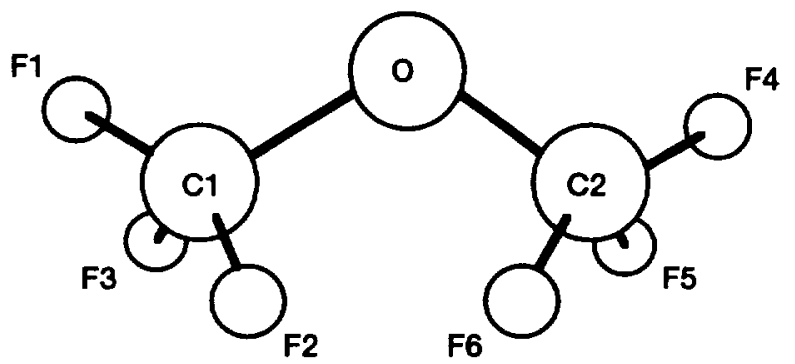

Figure 7.-Optimized structure of $\left(\mathrm{CF}_{3}\right)_{2} \mathrm{O}$. Cf. Table IV.

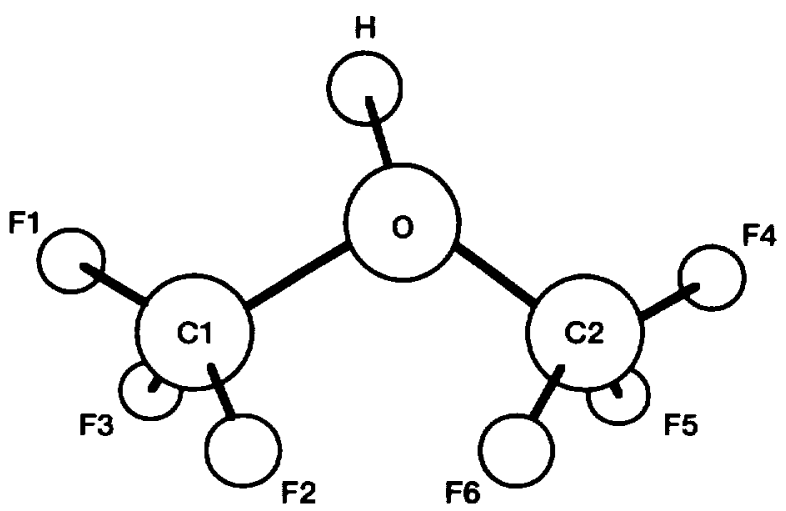

Figure 8.-Optimized structure of $\left(\mathrm{CF}_{3}\right)_{2} \mathrm{OH}^{+}$. Cf. Table IV. 

Public reporting burden for this collection of information is estimated to average 1 hour per response, including the time for reviewing instructions, searching existing data sources, gathering and maintaining the data needed, and completing and reviewing the collection of information. Send comments regarding this burden estimate or any other aspect of this collection of information, including suggestions for reducing this burden, to Washington Headquarters Services, Directorate for Information Operations and Reports, 1215 Jefferson Davis Highway, Suite 1204, Adtington, VA 22202-4302, and to the Office of Management and Budget, Paperwork Reduction Project (0704-0188), Washington, DC 20503.

\begin{tabular}{|l|l|l|}
\hline 1. AGENCY USE ONLY (Laave blank) & $\begin{array}{c}\text { 2. REPORT DATE } \\
\text { September 1996 }\end{array}$ & $\begin{array}{r}\text { 3. REPORT TYPE AND DATES COVERED } \\
\text { Technical Memorandum }\end{array}$ \\
\hline
\end{tabular}

4. TITLE AND SUBTITLE

5. FUNDING NUMBERS

Optimized Structures and Proton Affinities of Fluorinated Dimethyl Ethers: An Ab Initio Study

\section{AUTHOR(S)}

WU-505-63-5A

Victoria B. Orgel, David W. Ball, and Michael J. Zehe

7. PERFORMING ORGANIZATION NAME(S) AND ADDRESS(ES)

8. PERForming ORgANIZATION REPORT NUMBER

National Aeronautics and Space Administration

Lewis Research Center

Cleveland, Ohio 44135-3191

E-10369

9. SPONSORINGMONITORING AGENCY NAME(S) AND ADDRESS(ES)

10. SPONSORINGMONTTORING AGENCY REPORT NUMBER

National Aeronautics and Space Administration

Washington, D.C. $20546-0001$

NASA TM-107293

\section{SUPPLEMENTARY NOTES}

Victoria B. Orgel and David W. Ball, Cleveland State University, Department of Chemistry, Cleveland, Ohio 44115; Michael J. Zehe, NASA Lewis Research Center. Responsible person, Michael J. Zehe, organization code 5140 , (216) 433-5833.

12a. DISTRIBUTIONAVAILABILITY STATEMENT

12b. DISTRIBUTION CODE

Unclassified - Unlimited

Subject Categories 18, 19, and 23

This publication is available from the NASA Center for AeroSpace Information, (301) 621-0390.

13. ABSTRACT (Maximum 200 words)

$\mathrm{Ab}$ initio methods have been used to investigate the proton affinity and the geometry changes upon protonation for the molecules $\left(\mathrm{CH}_{3}\right)_{2} \mathrm{O},\left(\mathrm{CH}_{2} \mathrm{~F}\right)_{2} \mathrm{O},\left(\mathrm{CHF}_{2}\right)_{2} \mathrm{O}$, and $\left(\mathrm{CF}_{3}\right)_{2} \mathrm{O}$. Geometry optimizations were performed at the MP2/3-21G level, and the resulting geometries were used for single-point energy MP2/6-31G** calculations. The proton affinity calculated for $\left(\mathrm{CH}_{3}\right)_{2} \mathrm{O}$ was $7 \mathrm{Kjoule} / \mathrm{mole}$ from the experimental value, within the desired variance of $+1-8 \mathrm{Kjoule} / \mathrm{mole}$ for G2 theory, suggesting that the methodology used in this study is adequate for energy difference considerations. For $\left(\mathrm{CF}_{3}\right)_{2} \mathrm{O}$, the calculated proton affinity of $602 \mathrm{Kjoule} /$ mole suggests that perfluorinated ether molecules do not act as Lewis bases under normal circumstances; e.g. degradation of commercial lubricants in tribological applications.

\section{SUBJECT TERMS}

Proton affinity; Ab initio; Quantum chemistry; Structure

15. NUMBER OF PAGES

Proton affinity, Ab initio; Quantum chemistry, Structure

17. SECURITY CLASSIFICATION OF REPORT Unclassified
18. SECURTYY CLASSIFICATION OF THIS PAGE

Unclassified
19. SECURITY CLASSIFICATION OF ABSTRACT Unclassified
16. PRICE CODE

A03

20. LIMITATION OF ABSTRACT

Standard Form 298 (Rev. 2-89) Prescribed by ANSI Std. Z39-18 298-102 